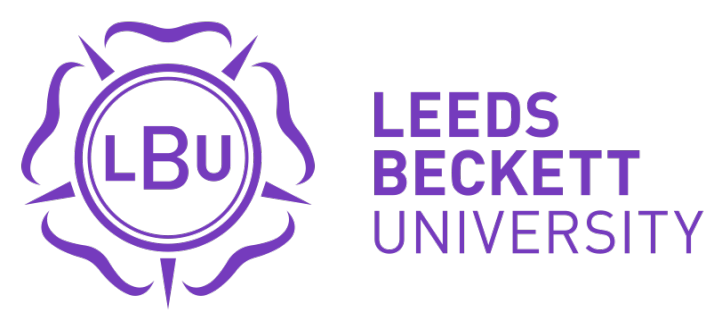

Citation:

Horbel, C and Popp, B and Woratschek, H and Wilson, B (2016) How context shapes value co-creation: Spectator experience of sport events. Service Industries Journal, 36 (11-12). pp. 510-531. ISSN 1743-9507 DOI: https://doi.org/10.1080/02642069.2016.1255730

Link to Leeds Beckett Repository record:

https://eprints.leedsbeckett.ac.uk/id/eprint/3161/

Document Version:

Article (Accepted Version)

The aim of the Leeds Beckett Repository is to provide open access to our research, as required by funder policies and permitted by publishers and copyright law.

The Leeds Beckett repository holds a wide range of publications, each of which has been checked for copyright and the relevant embargo period has been applied by the Research Services team.

We operate on a standard take-down policy. If you are the author or publisher of an output and you would like it removed from the repository, please contact us and we will investigate on a case-by-case basis.

Each thesis in the repository has been cleared where necessary by the author for third party copyright. If you would like a thesis to be removed from the repository or believe there is an issue with copyright, please contact us on openaccess@leedsbeckett.ac.uk and we will investigate on a case-by-case basis. 


\section{How context shapes value co-creation: Spectator experience of sport events}

Chris Horbel $^{\mathrm{a}^{*}}$, Bastian Popp ${ }^{\mathrm{b}}$, Herbert Woratschek $^{\mathrm{c}}$, and Bradley Wilson ${ }^{\mathrm{d}}$

${ }^{a}$ University of Southern Denmark,

Department of Sociology, Environmental and Business Economics,

Niels Bohrs Vej 9, DK-6700 Esbjerg, Denmark,

Tel.+45-6550-4238, horbel@sam.sdu.dk

${ }^{b}$ Leeds Beckett University, Carnegie Faculty, School of Sport, Cavendish Hall 211, Headingley, Leeds, LS6 3QU, UK,

Tel. +44-113-81-23173, b.popp@leedsbeckett.ac.uk

${ }^{c}$ University of Bayreuth, Department of Services Management, Universitaetsstrasse 30, 95447 Bayreuth, Germany,

Tel.+49-921-55-3497, Fax+49-921-55-3496,dlm@uni-bayreuth.de

${ }^{d}$ Universidad de Los Andes. Facultad de Administración, Building Julio Mario Santo Domingo. Block SD. Calle 21\#01-20, Barrio Las Aguas. Bogota, Colombia; and RMIT University, School of Media and Communication, 124 La Trobe Street, Melbourne, 3000, Australia, and University of Bayreuth, Department of Services Management, Universitaetsstrasse 30, 95447 Bayreuth, Germany, Tel.+57-1 3394949 ext.3960, bwilson@chariot.com.au

* Corresponding author

Forthcoming in:

The Service Industries Journal,

Special issue "Developing a Service Research Agenda in Sports" 


\section{How context shapes value co-creation: Spectator experience of sport events}

This paper applies the perspective of service-dominant logic, specifically value co-creation in service ecosystems to the context of sports. It builds on the notion that co-created value can only be understood as value-in-context. Therefore, a structural model is developed and tested for different contexts of spectating live broadcasts of football games during the Fédération Internationale de Football Association World Cup 2014. The context-specific contributions of the cocreating actors, spectators' experience evaluations, and the resulting contextspecific value perceptions from the spectators' perspective are identified. The results highlight that the relative influence of the main co-creating actors and the relative importance of the value dimensions differ across contexts. Service providers (in sports) should identify how consumers evaluate experience and which dimensions of value are most important to them in the context under consideration. This will help them to successfully facilitate value co-creation, make meaningful value propositions and achieve strategic benefit for themselves.

Keywords: service-dominant logic, service ecosystems, value co-creation, valuein-context, sport event experience 


\section{Introduction}

The extant literature on the service-dominant logic (Vargo \& Lusch, 2004) has put the focus on value creation, or more specifically, on value co-creation. In contrast to traditional production-oriented perspectives, various actors beyond the firm itself are involved in the process of value co-creation, including the customer (Payne, Storbacka, \& Frow, 2008; Prahalad \& Ramaswamy, 2004). Such understanding of value creation implies a shifting of the roles of the service provider from value delivery to making a value proposition to the customers. The provider's offering must then be integrated by the customer with other market-facing (i.e., service/s from other providers), public (i.e., public infrastructure) and his or her personal (e.g., knowledge and skills) resources in order to create value. Hence, the value determined also depends considerably on the consumer's own resource integration processes (Kleinaltenkamp, 2015; Pfisterer \& Roth, 2015).

The perspective of value co-creation in service ecosystems (Lusch \& Vargo, 2014; Vargo \& Akaka, 2012) almost intuitively implies that the context of the value creation process plays a pivotal role (Chandler \& Vargo, 2011). If the firm or service provider is no longer seen as the only actor that is responsible for creating value, it becomes apparent that the value created innumerably depends on the actors participating in value creation in a particular context. Furthermore, the resources, which are available to the actors and can be integrated in their value-creation processes, can vary dramatically depending on the context, in which value creation takes place.

Therefore, value co-creation is also referred to as value-in-context (Chandler \& Vargo, 2011).

In some industries, it is quite obvious that value is created through networks of actors. Even traditional models of sport event creation (e.g., Li, Hofacre, \& Mahony, 
2001) acknowledge that value is created by several firms or organizations (e.g., sport teams, league, event organizer, media). In addition, the contribution of the spectators themselves adds substantially to the value that is finally created. It is clearly visible as they sing battle chants and songs, perform choreographies or create banners and posters they show within and around the stadium. Furthermore, sport events can be experienced in different ways. Besides attending the event at the actual venue, sport events can also be consumed (in real-time, live) through different types of media, e.g. on television or via livestreaming. Major events are also often shown in public screening areas or on larger screens in sports bars.

These different consumption contexts are characterized by the involvement of different actors (e.g., fellow spectators, providers of food and drink, etc.) and various resources that can be integrated with the value propositions of other actors. Consequently, it is believed, that context impacts value creation in two ways. First, the actors that contribute to the creation of the overall event experience for the spectators are somewhat unique in each context. Second, due to the availability of different resources and the unique set of actors involved, the value rendered is also unique and is heavily dependent on the context, in which spectators experience the sport event. For the various service providers involved in value creation in a particular context it is highly relevant to understand to which degree they are able to actually influence the spectators' experience of the event. Taking into account that each single actor's influence on value is limited, it is highly critical to tailor their value proposition as best as possible to the needs of the spectators. In order to do this, it is further necessary to understand, which (aspects or dimensions of) value spectators derive from their experience. Therefore, this study takes a meso-level perspective of value co-creation for sport events (Woratschek, Horbel, \& Popp, 2014) and aims to answer the following 
research questions:

1. How do various actors contribute to spectators' experience of watching a sport event in different contexts?

2. How does spectators' perceived value of watching a sport event differ across contexts?

While it is clear in the literature that co-created value can only be understood as a notion derived from 'value-in-context' (Chandler \& Vargo, 2011), the empirical research so far has largely neglected a context-specific view. Therefore, this study makes a significant contribution by empirically investigating how value is created and perceived by customers in different contexts (Edvardsson, Tronvoll, \& Gruber, 2011). In doing so, this study contributes and extends the existing body of knowledge by applying the perspective suggested by service-dominant logic, in particular the notion of value co-creation in service ecosystems (Lusch \& Vargo, 2014). This research thereby also answers recent calls for applications of this new theoretical approach to the study of sport marketing (Tsiotsou \& Vargo, 2015) and sport management (Woratschek et al., 2014).

\section{Theoretical Background}

\section{Value co-creation and value-in-context}

Considering value as being co-created implies that value cannot be created through the activities of one actor, being it a firm or a customer. Hence, the classic understanding of value that can, ideally, be created through the production processes of a firm, and delivered by use of markets to customers, who can consume this value and often even destroy it, does not seem to capture the true nature of value creation and realization (Vargo \& Lusch, 2004, 2008, 2016). While one could argue, that the most basic form of value co-creation includes the collaboration of a firm and a customer, 
such a perspective must be considered an extreme over simplification, which neglects crucial aspects of the actual value creation process. The two focal actors (firm and customer) cannot co-create value without the integration of resources provided by private, market-facing, public and natural sources (Horbel, 2013; Lusch \& Vargo, 2014).

As the sources of resources that are available to the co-creating actors are dependent on the 'points in value creation time and space' (Vargo, 2009, p. 377), it becomes apparent that the value co-creation process is always unique. Value is therefore commonly understood as 'value-in-context' (Chandler \& Vargo, 2011) which is also inclusive of the particular notion of 'value-in-social-context' (Edvardsson et al., 2011). The contextual nature of value co-creation is captured in the foundational premise (FP) 10, recently also considered an axiom, i.e., an 'essence', of service-dominant logic: 'Value is always uniquely and phenomenologically determined by the beneficiary' (Lusch \& Vargo, 2014, p. 15 (FP 10); Vargo \& Lusch, 2016, p. 18 (axiom 4)).

The 'value-in-social-context' concept specifically refers to the dependency of individuals' value perception on their relative position in society, i.e., the importance of other social actors (Edvardsson et al., 2011). This perspective is also reflected in Vargo \& Lusch's (2016) definition of value co-creation as 'the actions of multiple actors, often unaware of each other, that contribute to each other's wellbeing' (p. 8). It emphasizes that value co-creation does not always require direct interaction between actors, but does often also include indirect resource provision and influences of others on value perception at a subconscious level. It further demonstrates that value is always cocreated in networks (Achrol \& Kotler, 1999), also called 'service systems' (Maglio, Vargo, Caswell, \& Spohrer, 2009) or 'service ecosystems' (Lusch \& Vargo, 2014; Vargo \& Lusch, 2011). The latter are defined as 'relatively self-contained, self- 
adjusting system(s) of resource-integrating actors connected by shared institutional logics (arrangements) and mutual value creation through service exchange' (Lusch \& Vargo, 2014, p. 24; Vargo \& Lusch, 2016, pp. 10-11). 'Service ecosystems' can be interpreted as subsystems of society and it has been suggested to analyze them at different levels: the intra-level (individual actors), micro-level (dyadic and triadic structures), the meso-level (midrange structures such as the entire, but specific value cocreation system) and the macro-level (entire economy or society) (Lusch \& Vargo, 2014; Woratschek et al., 2014).

A service ecosystem as a self-adjusting system has the "built-in ability to regulate itself through self-adjusting processes" (Lusch \& Vargo, 2014, p. 164), which allows them to change its structure according to the context of value co-creation. The (social) context particularly determines which parts of a larger ecosystem (e.g., an industry or the entire economy) are activated in a value co-creation process. The resulting context-specific constellation of actors and their relationships influences how actors co-create and perceive value in two ways. While other social actors more or less directly influence the process of value co-creation through interaction, provision of resources and mutual service exchange, consumer's value perceptions, at least in part, also depend on the structural dimension of the wider social context of value creation (Edvardsson et al., 2011). These structures, i.e., institutions (e.g., norms, meanings, symbols, laws, practices) and institutional arrangements (interrelated sets of institutions) are not only essential to facilitate interaction and collaboration in service ecosystems, but also influence how beneficiaries interpret and determine value (Vargo \& Lusch, 2016).

Whilst we acknowledge this twofold influence of context on value co-creation and the importance of structures and institutions for value generation, this article will be 
focused on the influence of the resources contributed by and interactions with contextspecific actors on consumers' perception of value when experiencing a sport event. Hence, the specific focus is on how different context-specific constellations of service ecosystems in terms of the involved actors influence actors' value creation and perception.

\section{Context and consumer experience}

As this study focuses on the value perceptions of consumers it fits within the domain of Consumer Culture Theory (CCT) (Arnould \& Thompson, 2005). In fact, service-dominant logic and CCT have been recognized as 'natural allies' (Arnould, 2007) in understanding value co-creation. Several researchers have started to link and converge the perspectives of CCT, consumer experiences and value co-creation (Akaka, Vargo, \& Schau, 2015; Arnould, 2007; Helkkula, Kelleher, \& Pihlström, 2012).

Whereas service-dominant logic and its service-ecosystem-perspective focusses on resource integration and mutual service provision of the co-creating actors, but also recognizes the facilitating character of institutions and institutional arrangements, CCT more explicitly focuses on the latter (Akaka et al., 2015). More specifically, it provides 'a more in-depth understanding of cultural aspects of experience' (Akaka et al., 2015, p. 212) from the consumer's perspective. According to CCT, the value consumers derive from an experience 'goes well beyond the interaction between service customer/customers and the service provider' (Helkkula et al., 2012, p. 11) and includes existing and imaginary customer practices shaped by consumers' social contexts ('lifeworlds').

Additionally, CCT points towards the fact, that social structures, for example common values (Schouten \& McAlexander, 1995), as they are embedded within subcultures of consumption or brand communities, as well as the consumers' relative 
position within the wider social system influence overall consumer experience (Arnould \& Thompson, 2005; Edvardsson et al., 2011). Vargo and Lusch (2011) support this perspective and broaden it by suggesting that social structures or 'institutions' not only facilitate the interaction among actors and the evaluation of experiences, but are also influenced and changed through them. In the sport event example, spectators' experience is influenced by broader societal norms and values, but often also through the common values of the fan community (Tsiotsou, 2016). However, these norms and values are not fixed or pre-existing, but are constantly shaped through the influence of multiple actors, such as media, sponsors, and the fans themselves.

\section{Conceptual Model of Sport Event Experience}

\section{Research context}

The sport's business, in particular a sport event, is selected in this study as it is an ideal application of contextual value co-creation. It is quite obvious that a customer's experience at a sport event depends not only on the game that is played, and the meaning that he assigns to the game, the team brand, individual players, etc., but also on his past experiences with the teams playing, the league, tournament, or the sport in general and various other factors that shape his expectation, such as preceding reports on television, in newspapers, or in online and social media, and conversations with friends and family.

For this study, the Fédération Internationale de Football Association (FIFA) World Cup 2014 has been chosen for developing a conceptual model of spectators' sport event experience and the value created for and with them. This application is particularly interesting as spectators commonly experience games of the FIFA World Cup in different contexts. Due to limited stadium capacities, the financial constraints of spectators, and large distances between fans and the host country, by far the most 
viewed form is through broadcasts. In line with the results of an audience analysis for the latest FIFA World Cup in 2014 (Gerhard \& Zubayr, 2014), we identified four most relevant contexts for watching broadcasts of the games:

1. 'Public screening': Collective spectatorship (Becker, Kautsky, \& Widholm, 2014), i.e., spectators watching live broadcasts of sport events in a public place together with a large (mostly unknown) audience, has become very common as a way to experience a sport event. Such live public screenings (e.g. at fan parks) have become particularly popular since the 2006 FIFA World Cup in Germany and since then have been established as an option to watch big sport events. During the FIFA World Cup 2014, for example, on average 8.9 per cent (3.30 Mio.) of the German audience watched the games of the German team at a public screening event (Gerhard \& Zubayr, 2014).

2. 'Bar/ pub/ restaurant': While watching broadcasts of football matches at a bar, pub or restaurant has many commonalities with collective spectatorship at a public screening site, there are some fundamental differences, characterizing them as a different context. First, these locations provide fans with access to a broad variety of sport events on a more regular basis than public screenings, for example during a whole season of a sports league (Weed, 2007). Hence, spectators are generally more familiar with such viewing sites and the involved actors. Second, the number of actors contributing the service quality aspects to the consumption context (e.g., food, drink, security) is often much lower than at a public screening event. Third, broadcasts in bars, pubs or restaurants are of a much smaller-scale than a public screening event and hence, this context is usually characterized by less anonymity of the audience. Spectators have also used bars, pubs and restaurants intensively during the FIFA World Cup 2014. 
On average 8.7 per cent (3.23 Mio.) of the spectators watched the games of the German national team in such context (Gerhard \& Zubayr, 2014).

3. 'Viewing with others at home': The social uses of television are well known (Lull, 1980). Watching live broadcasts of football games often is practiced as a social experience together with friends and family at home. In fact, over 90 per cent of the German viewers of the FIFA World Cup 2014 indicated that they want to share their experience with others (Tomorrow Focus Media, 2014). In contrast to collective spectatorship in public places or in bars, pubs, and restaurants, there are usually no pre-defined actors, which contribute the service quality aspects of the consumption context. However, resources in a 'home'context may be similar to the two 'public' contexts if, for example home delivered food and drink are consumed.

4. 'Viewing alone at home': While many spectators enjoy the company of others when watching football games, there are also spectators who watch the live broadcast of a game alone at home. Notably, even though there is no direct interaction between actors in such context, value is still co-created, but through more indirect forms of resource integration and mutual service provision.

\section{Context-specific actors and their contributions to the sport event experience}

Our first research question is directed at a better understanding of the contextspecific actors' contribution to the customer experience. In the case of sport events, a large number of actors are naturally involved in value co-creation: teams competing in the game, sponsors providing money and supplies, facility owners providing a sound stage and venue, caterers offering food and drinks, police and private security firms ensuring safety, public transport and providers of parking services making sure that visitors can reach and enter the venue in a timely fashion, and, the various kinds of 
visitors, such as hard core fans of both the own and the opposing team, families, business guests, occasional spectators, etc. meshing to create an overall event atmosphere (Uhrich \& Benkenstein, 2012). One study cannot do all of these elements justice. In the context of team sport events, we suggest that three types of actors are particularly important for value co-creation. First, the opposing teams naturally contribute to spectators' experience of the game. Considering the argument of Vargo and Lusch (2008) that value is always determined by the beneficiary, we conceptualize the value contribution of the actual game as 'perceived team performance'. This concept not only represents the outcome of the game, but also spectator perceptions of team effort and player enthusiasm during the contest (Gladden \& Funk, 2001). Spectators' subjective evaluation of team performance could, for example, be influenced by their level of identification with their own team which provides them with additional benefits and leads to a more positive evaluation of the team's performance (Fournier, 1998;

Stokburger-Sauer, Bauer, \& Mäder, 2008). Moreover, this conceptualization deliberately focusses on those team-related aspects which both are directly related to the event experience and can be influenced by the team.

\section{$H_{1}$ : $\quad$ Perceived team performance exerts a positive effect on overall event experience.}

Second, the organizer of the event at the venue, being it the stadium itself, a public screening area or a bar, is an important contributor to the visitor's experience as the organizer considerably determines the context in which spectators are able to create value through the event experience (Edvardsson, Enquist, \& Johnston, 2005). This notion is supported by research on the importance of 'servicescapes' in sport (Wakefield \& Blodgett, 1994)

\section{$\mathrm{H}_{2}$ : $\quad$ Perceived service quality of the consumption context exerts a positive}


effect on overall event experience.

Third, visitors' experience and the value created at a sport event is also heavily influenced by the fans and spectators themselves (Chang \& Horng, 2010). The influence of other spectators on the individual's experience can be explained by social identity theory (Tajfel, 1978). Belonging to membership reference groups or feeling identified, attracted to, and psychologically involved with aspirational reference groups strengthens individuals' self-worth (White, Argo, \& Sengupta, 2012). Consequently, the more spectators feel such feeling of belonging to other fans or spectators, the more will their contributions influence the individual's experience. As Uhrich and Benkenstein (2012) demonstrate, other fans and spectators, especially through their behaviour (e.g., by singing battle chants), but also through their appearance (e.g., wearing fan merchandise) and their mere presence and swelling numbers contribute substantially to the atmospherics at a sports stadium. Hence, spectator-induced atmosphere which comprises the stimuli emanating from the spectator and their behaviour is an important component of sport stadium atmosphere (Uhrich \& Benkenstein, 2010, 2012).

It is believed that other spectators equally contribute to viewers' experiences of sport games when they watch them in other public places (e.g. public screening areas, sports bars) or even at their homes together with others on TV. Hence, we expect a positive influence of 'spectator-induced atmosphere' on the spectator's experience.

\section{H. $\quad$ Perceived spectator-induced atmosphere exerts a positive effect on overall event experience.}

Our hypotheses $\mathrm{H}_{1}-\mathrm{H}_{3}$ postulate that the same three generic types of actors influence spectators' experience and hence the value created for and with them across contexts. However, while the teams performing the game $\left(\mathrm{H}_{1}\right)$ are the same in all four contexts under investigation, this is quite obviously not the case for the other actors 
involved in co-creating the event experience. For example, the actual actors contributing service-quality-related aspects of the consumption contexts (i.e., "service providers"; $\mathrm{H}_{2}$ ) are at least partly different within the four contexts. Different providers of food and drinks, security, or hospitality are included in the different scenarios and contribute in different ways and to different extent. While service staff through more extensive interaction with the patrons can have considerable influence on overall value when consuming the event on a screen in a bar, this might be of less importance in a public screening area and probably even less relevant when spectators watch the game on TV at home. However, some actors might still be the same across contexts, for example a stadium announcer whose statements can be heard in the broadcasts of the game.

Clearly, the actual set of other spectators influencing the experience $\left(\mathrm{H}_{3}\right)$ is also different across the contexts. Other spectators might be more (e.g., when watching the game at home with friends) or less (e.g., when watching the game at a public screening site) known to the individual leading to different types of interaction with them. When a fan watches the game alone at home on TV, he might have almost no interaction with other spectators. However, sometimes people may engage with others in textmessaging, phone calls or fan blogs during the game even if alone.

As a consequence, the actual set of relevant actors and hence, the social structure of the context changes, when spectators watch the event at home on TV alone or with others compared to a public setting, for example a live screening in a public place or in a sports bar. In addition, the interaction with other spectators can take multiple forms that influence viewers' experience evaluation and value in very different ways, both positively and negatively (Wu, 2008). CCT suggests, that consumers' experiences are considerably influenced by the social structures they are embedded in (Arnould \& Thompson, 2005; Edvardsson et al., 2011). Consequently, we anticipate that the relative 
influence of the different types of actors on spectators' experience and value perceptions will vary across contexts.

To analyze the salience of different actor contributions to spectators' experience, the proposed model will therefore be tested in the four different sport event contexts.

\section{Perceived value-in-context}

The conceptualization of co-created value has been rather fuzzy (Grönroos \& Voima, 2013) and hence, approaches to its measurement to this point in time are rather limited. This article focuses on value from the perspective of one particular group of actors within the value-creation ecosystem of a sport event, i.e. the spectators. Consequently, the focus of our second research question is on capturing the value as this particular group of actors experiences it in different contexts.

Consumers' motivations are generally regarded as an important driving force for behavior and can therefore be interpreted as fundamental in co-creating value in a service exchange. Wang, Min, and Kim (2013) demonstrate that the fulfillment of spectator motives is the main driver for sport spectators' wellbeing, which includes consumers' pleasure, happiness, and self-actualization. We therefore use the fulfilment of consumers' motives for sport spectatorship to conceptualize their perceived value.

Motives that drive fans to attend games and live competitions have been studied extensively in the past. A variety of motivational scales have been developed such as the Sport Fan Motivation Scale (Wann, 1995), the Motivation Scale for Sport Consumption (Trail \& James, 2001), the Sport Interests Inventory (Funk, Mahony, \& Ridinger, 2002), and the Sporting Event Experience Scale (Bouchet, Bodet, BernacheAssollant, \& Kada, 2011). While most studies of sport fan motivation have been completed for live spectating of sport events at the actual venues, Schafmeister (2007) specifically analyzed motives for watching sports on TV and found very similar motives 
compared to the ones outlined pertaining to live attendance. However, additional motives (intercultural contacts, freedom to move freely around the event venue) have been identified for a public screening context (Durchholz, 2012).

Furthermore, social identity theory clearly attaches great importance to social identification in everyday life. Similar to motivations, identification does influence individual behavior (Tajfel, 1978). Consumers engage in value co-creation processes with other actors in order to reach a psychological state of perceiving, feeling, and valuing their belongingness with these actors (Lam, Ahearne, Mullins, Hayati, \& Schillewaert, 2013). Such feelings of belongingness strengthen their self-worth (White et al., 2012). Hence, event experiences which provide them with such feelings will support the fulfilment of their need for identification. We therefore assume that the fulfilment of consumers' identification with a service provider represents another dimension of the overall value they perceive within the service experience.

\section{Table 1: Motives for Sport Spectatorship}

\begin{tabular}{|c|c|}
\hline Key Sport Spectatorship Motives & Selected Sources \\
\hline Fun and Entertainment & $\begin{array}{l}\text { Jamens and Ross (2004); Won and Kitamura (2007); Wann, } \\
\text { Melnick, Russel, and Pease (2001) }\end{array}$ \\
\hline Atmosphere & Uhrich and Benkenstein $(2010,2012)$ \\
\hline Physical Attractiveness and Aesthetics & $\begin{array}{l}\text { Trail, Anderson, and Fink (2003); Wann, Melnick, Russel, } \\
\text { and Pease (2001) }\end{array}$ \\
\hline Eustress and Tension & $\begin{array}{l}\text { Funk, Ridinger, and Moorman (2004); Trail, Anderson, and } \\
\text { Fink (2003)Wann (1995); Wann, Melnick, Russel, and Pease } \\
\text { (2001) }\end{array}$ \\
\hline Freedom to Move Around & (Durchholz, 2012) \\
\hline Social Contacts and Interaction & $\begin{array}{l}\text { Trail, Anderson, and Fink (2003); Wann, Melnick, Russel, } \\
\text { and Pease (2001) }\end{array}$ \\
\hline Intercultural Contact & (Durchholz, 2012) \\
\hline Identification with Team & $\begin{array}{l}\text { Donavan, Carlson, and Zimmermann (2005); Schafmeister } \\
\text { (2007) }\end{array}$ \\
\hline Identification with Sport Event & $\begin{array}{l}\text { Donavan, Carlson, and Zimmermann (2005); Schafmeister } \\
\text { (2007) }\end{array}$ \\
\hline
\end{tabular}

Table 1 provides an overview of the motives of sport spectatorship selected for this study. While we are aware that even more spectatorship motives have been 
discussed in previous research, this selection includes the most relevant motives that have been studied in relation to the four consumption contexts under investigation in this study (e.g., stadium, pub, TV).

In line with Macdonald, Wilson, Martinez, and Toossi (2011) who define ‘value-in-use as a customer's outcome, purpose or objective that is achieved through service' (p. 671), we assume that event experience contributes to the satisfaction of the above presented motives of sport spectators and their identification with sport eventrelated targets of identification. We therefore propose the following hypotheses:

H4-12: Event experience positively influences the fulfilment of perceived value dimensions including 'fun and entertainment' $\left(\mathrm{H}_{4}\right)$, 'atmosphere' $\left(\mathrm{H}_{5}\right)$, 'physical attractiveness and aesthetics' $\left(H_{6}\right)$, 'eustress and tension' $\left(H_{7}\right)$, 'freedom to move around' ( $\left.H_{8}\right)$, 'social contacts and interaction' $\left(H_{9}\right)$, 'intercultural contact' $\left(H_{10}\right)$, 'team identification' $\left(H_{11}\right)$, and 'identification with the event' $\left(H_{12}\right)$.

We further assume that the dimensions of perceived value are differently affected by spectators' experience in the four sport event viewing contexts under study. In each of those contexts, spectators have access to different resources, provided by different actors. Following FP 6 of the service-dominant logic that "value is co-created by multiple actors, always including the beneficiary" (Vargo \& Lusch, 2016, p. 9), it can be concluded that the value created for and with spectators is the result of the integration of resources provided by the specific actors involved. We expect that some motives can be better fulfilled by integrating particular resources than others. Therefore, the satisfaction of the different motives has different weight within the overall value determined by spectators depending on the context.

Figure 1 outlines the conceptual model based on the above theoretical 
considerations and hypotheses. Thereafter, we assume that consumers' event experience is predominantly determined by the contributions of the core actors involved in cocreating value at a sport event, i.e., by the performance of the team, the provider of the event venue and the atmosphere that is created by the spectators themselves in this process. Spectators' evaluation of the event experience drives their value perception, which consists of different dimensions representing the fulfilment of their needs relating to their motives and sought levels of identification.

\section{Figure 1: Conceptual Model}

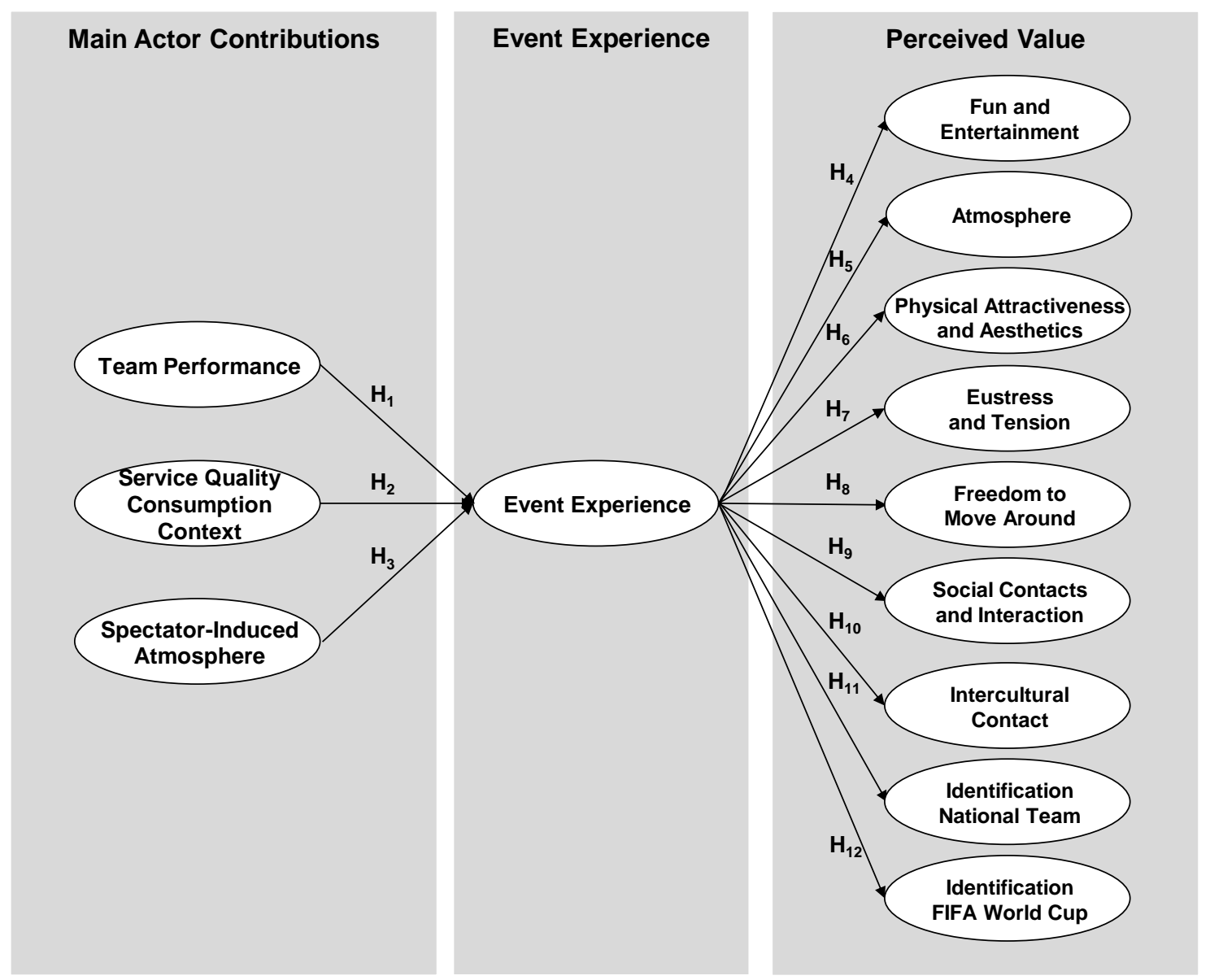

\section{Empirical Study}

\section{Methodology}

We collected data via a self-administered online survey of spectators of the 
German national team games during the FIFA World Cup 2014 in Brazil. Respondents were invited by mail and online posts to participate in the survey. The survey addressed spectators who had not watched the games at the actual event venue, but through live broadcastings in the different contexts described above. Of the 532 respondents who participated in the survey, 127 had watched the game at a public screening, 86 in a bar, pub, or restaurant, 261 at home together with others, and 54 had watched it alone at their homes.

Participants were first asked whether they had already seen a game of the German national team at the World Cup and were requested to reveal which game it was. Respondents who had seen more than one game were asked to choose the game they remembered best and relate their subsequent answers to this game. In the following, the game selected by the individual respondent was explicitly mentioned in all questions of the questionnaire. Through this procedure, data for all seven games of the German national team was collected whereby slightly more responses were received for games during the group stage of the tournament.

Using a scale from 1 to 10 , all respondents initially were asked to indicate to what degree the particular game matched their expectation of a perfect football experience. Thereafter, all other constructs in our sample were measured based on existing scales from previous studies using seven-point Likert scales ranging from 'strongly agree' to 'strongly disagree'.

Three items were chosen to measure 'perceived team performance' (Beccarini \& Ferrand, 2006; Madrigal, 1995). Moreover, based on existing scales for measuring the quality of servicescapes, particularly in the context of sports (Brady \& Cronin, 2001; Fernandes \& Neves, 2014; Wakefield, Blodgett, \& Sloan, 1996), three items measuring the aspects, which are attributed to the organizer were developed and slightly adapted to 
each context. We used a rather global-type measure for all services that could be provided by event organizers and did not get into more detail as the specific services differ across contexts. 'Spectator-induced atmosphere' was measured by three reflective items adapted from Uhrich and Benkenstein's $(2010,2012)$ studies on atmosphere in sports.

The dimensions of perceived value were measured as the fulfilment of spectators' motivations (Durchholz, 2012). In particular, two-item or three-item scales established from previous research were adapted to measure 'fun and entertainment' (James \& Ross, 2004; Won \& Kitamura, 2007), 'atmosphere' (Uhrich \& Benkenstein, 2010, 2012), 'physical attractiveness and aesthetics' (Trail, Anderson, \& Fink, 2003), 'eustress and tension' (Funk et al., 2002; Wann, 1995), 'social contacts and interaction' (Trail et al., 2003), 'freedom to move around' and 'intercultural contact' (Durchholz, 2012). Furthermore, identification with the national team and identification with FIFA were captured. Both were measured using a well-established six-item scale (Donavan, Carlson, \& Zimmermann, 2005; Mael \& Ashforth, 1992; Trail et al., 2003). Appendix 1 provides an overview of the items representing all constructs studied.

It was deemed prudent given the exploratory nature of this study to use Partial Least Squares (PLS) Path Modeling (Hair, Sarstedt, Ringle, \& Mena, 2012). The PLS approach was implemented for several reasons. First, PLS demonstrates excellent convergence behavior for small sample sizes (Reinartz, Haenlein, \& Henseler, 2009). Second, PLS is not constrained by identification concerns, even if models become complex (Hair et al., 2012). Third, the PLS algorithm more sensitively handles data that violates the normality assumption which is common in marketing studies (Henseler, Ringle, \& Sinkovics, 2009).

As a first step, four separate analyses for each structural model, i.e. one for each 
context, were estimated. For the contexts 'together with friends at home' and 'alone at home' some constructs (i.e. 'service quality consumption context') and several single items, which did not apply to the respective context were not included in the questionnaire and hence, were excluded from the analysis. As a second step, a multigroup analysis using the parametric approach (Sarstedt, Henseler, \& Ringle, 2011) was conducted in order to compare the models of the contexts 'public screening' and 'bar/pub/restaurant', as both represent public consumption contexts and therefore the conceptualizations of all constructs are similar.

\section{Common method variance}

Given that our study only includes consumer self-reported data, common method variance should be explored. We mitigated the propensity to have common method variance by using procedural remedies such as the use of previously validated scales, proximal separation between predictor and criterion constructs, and variation of scale points (Podsakoff, MacKenzie, \& Podsakoff, 2012). Moreover, we tested for common method variance using Harman's single-factor test (Harman, 1976). This demonstrated that none of the factors accounted for the majority of covariance among items thus indicating that common method bias is not a threat to further analyses.

\section{Analysis of measurement models}

For each context, the measurement models were estimated separately and inspected with regards to suitable validity and reliability levels. This was to ensure construct and discriminant validity and to determine item suitability. Table 2 reports the key statistics and loadings for each and across contexts. The assessment of the measurement models revealed that the vast majority of loadings were acceptable $(>.707)$ within a range of .71 and .97. Only in the 'viewing alone at home' context, two items were .60 and .64 , and hence, below the typical cut-offs. However, following the 
recommendation of Chin (1998), they were still retained in the analyses. This is common practice in first time studies and works of an exploratory nature (Wilson, 2010). Construct reliabilities ranged between .85 and .96 (resp. 1 for the single item construct 'event experience'). The AVE ranged between .70 and .91 (resp. 1 for the single item construct 'event experience'). To assess discriminant validity all square roots of AVE were calculated and are clearly shown to be greater than the respective correlations between constructs (Fornell \& Larcker, 1981). This was further corroborated with an inspection of the cross-loadings revealing suitable loadings patterns, i.e., items more strongly loaded on their posited construct.

Table 2: Measurement Model

\begin{tabular}{|c|c|c|c|c|c|c|c|c|c|}
\hline Construct & $\begin{array}{l}\text { No. } \\
\text { of } \\
\text { Ind. }\end{array}$ & & Item $\mathbf{L}$ & oading $(\lambda) \mathbf{R}$ & Range $^{a}$ & & $\operatorname{Alpha}^{b}(\alpha)$ & $\begin{array}{l}\text { Comp } \\
\operatorname{Rel}^{\mathbf{c}} \\
(\rho \xi \mathbf{X})\end{array}$ & $\mathbf{A V E} \mathbf{E}^{\mathbf{d}}$ \\
\hline Context & & $\begin{array}{c}\text { Public } \\
\text { Screening }\end{array}$ & $\begin{array}{c}\text { Bar/ Pub/ } \\
\text { Restaurant }\end{array}$ & $\begin{array}{l}\text { Viewing } \\
\text { with Others } \\
\text { at Home }\end{array}$ & $\begin{array}{l}\text { Viewing } \\
\text { Alone at } \\
\text { Home }\end{array}$ & $\begin{array}{l}\text { Across all } \\
\text { Contexts }\end{array}$ & $\begin{array}{l}\text { Across all } \\
\text { Contexts }\end{array}$ & $\begin{array}{l}\text { Across all } \\
\text { Contexts }\end{array}$ & $\begin{array}{l}\text { Across all } \\
\text { Contexts }\end{array}$ \\
\hline $\begin{array}{l}\text { Service Quality Con- } \\
\text { sumption Context }\end{array}$ & $4^{e}$ & $.83 \rightarrow .91$ & $.86 \rightarrow .96$ & $\mathrm{n} / \mathrm{a}$ & $\mathrm{n} / \mathrm{a}$ & $.83 \rightarrow .96$ & $.90 \rightarrow .94$ & $.93 \rightarrow .96$ & $.77 \rightarrow .85$ \\
\hline $\begin{array}{l}\text { Spectator-Induced } \\
\text { Atmosphere }\end{array}$ & 3 & $.85 \rightarrow .90$ & $.87 \rightarrow .90$ & $.86 \rightarrow .92$ & $.76 \rightarrow .90$ & $.85 \rightarrow .92$ & $.80 \rightarrow .88$ & $.88 \rightarrow .93$ & $.71 \rightarrow .81$ \\
\hline Team Performance & 3 & $.77 \rightarrow .91$ & $.83 \rightarrow .93$ & $.80 \rightarrow .92$ & $.60 \rightarrow .96$ & $.60 \rightarrow .96$ & $.80 \rightarrow .87$ & $.88 \rightarrow .92$ & $.72 \rightarrow .79$ \\
\hline Event Experience & 1 & 1 & 1 & 1 & 1 & 1 & 1 & 1 & 1 \\
\hline Atmosphere & 3 & $.89 \rightarrow .95$ & $.90 \rightarrow .95$ & $.94 \rightarrow .94$ & $.94 \rightarrow .96$ & $.89 \rightarrow .96$ & $.92 \rightarrow .94$ & $.95 \rightarrow .96$ & $.86 \rightarrow .90$ \\
\hline Eustress and Tension & 3 & $.82 \rightarrow .88$ & $.77 \rightarrow .90$ & $.80 \rightarrow .88$ & $.64 \rightarrow .97$ & $.64 \rightarrow .97$ & $.80 \rightarrow .82$ & $.87 \rightarrow .89$ & $.70 \rightarrow .73$ \\
\hline $\begin{array}{l}\text { Freedom to Move } \\
\text { Around }\end{array}$ & $2^{\mathrm{e}}$ & $.91 \rightarrow .97$ & $.93 \rightarrow .94$ & 1 & 1 & $.91 \rightarrow 1$ & $.88 \rightarrow 1$ & $.94 \rightarrow 1$ & $.88 \rightarrow 1$ \\
\hline Intercultural Contact & $2^{\mathrm{e}}$ & $.90 \rightarrow .94$ & $.85 \rightarrow .88$ & $.76 \rightarrow .98$ & $\mathrm{n} / \mathrm{a}$ & $.76 \rightarrow .98$ & $.66 \rightarrow .82$ & $.85 \rightarrow .22$ & $.74 \rightarrow .85$ \\
\hline $\begin{array}{l}\text { Identification FIFA } \\
\text { World Cup }\end{array}$ & 6 & $.87 \rightarrow .92$ & $.81 \rightarrow .93$ & $.86 \rightarrow .93$ & $.85 \rightarrow .92$ & $.85 \rightarrow .93$ & $.94 \rightarrow .95$ & $.95 \rightarrow .96$ & $.78 \rightarrow .81$ \\
\hline $\begin{array}{l}\text { Identification } \\
\text { National Team }\end{array}$ & 6 & $.87 \rightarrow .91$ & $.85 \rightarrow .93$ & $.89 \rightarrow .93$ & $.83 \rightarrow .95$ & $.83 \rightarrow .95$ & $.95 \rightarrow .95$ & $.96 \rightarrow .95$ & $.78 \rightarrow .81$ \\
\hline $\begin{array}{l}\text { Physical Attractive- } \\
\text { ness and Aesthetics }\end{array}$ & 3 & $.82 \rightarrow .90$ & $.82 \rightarrow .89$ & $.85 \rightarrow .91$ & $.91 \rightarrow .92$ & $.82 \rightarrow .92$ & $.81 \rightarrow .92$ & $.89 \rightarrow .95$ & $.73 \rightarrow .86$ \\
\hline $\begin{array}{l}\text { Social Contacts and } \\
\text { Interaction }\end{array}$ & $2^{\mathrm{e}}$ & $.90 \rightarrow .92$ & $.86 \rightarrow .91$ & $.92 \rightarrow .92$ & $.86 \rightarrow .92$ & $\mathrm{n} / \mathrm{a}$ & $.73 \rightarrow .82$ & $.88 \rightarrow .91$ & $.83 \rightarrow .84$ \\
\hline $\begin{array}{l}\text { Fun and } \\
\text { Entertainment }\end{array}$ & 2 & $.94 \rightarrow .95$ & $.93 \rightarrow .96$ & $.71 \rightarrow .85$ & $.94 \rightarrow .94$ & $.71 \rightarrow .96$ & $.86 \rightarrow .90$ & $.94 \rightarrow .95$ & $.88 \rightarrow .91$ \\
\hline \multicolumn{10}{|c|}{$\begin{array}{l}\text { Note: } a=\text { Highest and lowest loading within context; } b=\text { Highest and lowest Cronbach's Alpha across all contexts; } c= \\
\text { Highest and lowest Composite Reliability across all contexts; } d=\text { Highest and lowest Average Variance Extracted }(A V E) \\
\text { across all contexts; } e=\text { not applicable for all contexts. }\end{array}$} \\
\hline
\end{tabular}




\section{Analysis of structural relations and hypothesis testing}

The empirical findings of the structural model estimates and the significance of the path coefficients using the PLS bootstrapping procedure (Chin, 2010) confirm most of the hypotheses for each context. However, the results also reveal differences between the contexts. Regarding the main actor contributions, in the three contexts 'bar/ pub/ restaurant', 'viewing with others at home', and 'viewing alone at home' significant positive effects of 'team performance' on 'event experience' have been found, whereas 'spectator-induced atmosphere' and 'service quality consumption context' have no significant influence (or do not apply to these contexts). In contrast, reverse effects are observed for the 'public screening' context.

Table 3. Empirical Results

\begin{tabular}{|c|c|c|c|c|c|c|c|c|}
\hline & \multicolumn{2}{|c|}{$\begin{array}{c}\text { Public } \\
\text { Screening }\end{array}$} & \multicolumn{2}{|c|}{$\begin{array}{l}\text { Bar/ Pub/ } \\
\text { Restaurant }\end{array}$} & \multicolumn{2}{|c|}{$\begin{array}{c}\text { Viewing with } \\
\text { Others at } \\
\text { Home } \\
\end{array}$} & \multicolumn{2}{|c|}{$\begin{array}{c}\text { Viewing Alone } \\
\text { at Home }\end{array}$} \\
\hline & $\begin{array}{l}\text { Path } \\
\text { coeff. }\end{array}$ & t-value & $\begin{array}{l}\text { Path } \\
\text { coeff. }\end{array}$ & t-value & $\begin{array}{l}\text { Path } \\
\text { coeff. }\end{array}$ & t-value & $\begin{array}{l}\text { Path } \\
\text { coeff. }\end{array}$ & t-value \\
\hline \multicolumn{9}{|l|}{ Main Actor Contributions --> Experience } \\
\hline $\mathrm{H}_{1}:$ Team Performance --> Experience & $.11^{*}$ & 1.67 & $.38^{* * *}$ & 2.80 & $.57^{* *}$ & 9.23 & $.34^{*}$ & 2.53 \\
\hline $\begin{array}{l}\mathrm{H}_{2} \text { : Service Quality Consumption Context --> } \\
\text { Experience }\end{array}$ & $.36^{* *}$ & 5.32 & .18 & 1.48 & $\mathrm{n} / \mathrm{a}$ & $\mathrm{n} / \mathrm{a}$ & $\mathrm{n} / \mathrm{a}$ & $\mathrm{n} / \mathrm{a}$ \\
\hline $\mathrm{H}_{3}$ : Spectator-Induced Atmosphere --> Experience & $.23^{* *}$ & 2.90 & .14 & .94 & .10 & 1.60 & .14 & .93 \\
\hline \multicolumn{9}{|l|}{ Experience --> Perceived Value Dimensions } \\
\hline $\mathrm{H}_{4}$ : Experience --> Fun and Entertainment & .66 & 1.44 & $.72^{* *}$ & 12.11 & $.76^{* *}$ & 26.10 & $.65^{* *}$ & 7.84 \\
\hline $\mathrm{H}_{5}:$ Experience --> Atmosphere & $.50^{* *}$ & 6.80 & $.53^{* *}$ & 7.21 & $.66^{* *}$ & 17.44 & $.57^{* *}$ & 6.10 \\
\hline $\mathrm{H}_{6}$ : Experience --> Physical Attractiveness and Aesthetics & $.31^{* *}$ & 3.81 & $.52^{* *}$ & 7.00 & $.62^{* *}$ & 13.64 & $.50^{* *}$ & 4.65 \\
\hline $\mathrm{H}_{7}$ : Experience --> Eustress and Tension & $.34^{* *}$ & 4.20 & $.23^{*}$ & 2.38 & $.40^{* *}$ & 6.58 & .08 & .35 \\
\hline H8: Experience --> Freedom to Move Around & .05 & .46 & $.16^{*}$ & 2.03 & .01 & .20 & -.03 & .22 \\
\hline $\mathrm{H}_{9}$ : Experience --> Social Contacts and Interaction & $.43^{* *}$ & 4.97 & $.42^{* * *}$ & 3.85 & $.24^{* *}$ & 3.68 & $\mathrm{n} / \mathrm{a}$ & $\mathrm{n} / \mathrm{a}$ \\
\hline $\mathrm{H}_{10}:$ Experience --> Intercultural Contact & .08 & .76 & .14 & 1.32 & -.09 & 1.14 & $\mathrm{n} / \mathrm{a}$ & $\mathrm{n} / \mathrm{a}$ \\
\hline $\mathrm{H}_{11}$ : Experience --> Identification National Team & $.31^{* *}$ & 3.61 & $.33^{* * *}$ & 4.59 & $.36^{* *}$ & 6.14 & .21 & 1.07 \\
\hline $\mathrm{H}_{12}$ : Experience --> Identification World Cup & $.17^{*}$ & 1.85 & $.26^{*}$ & 2.53 & $.28^{* *}$ & 4.95 & .27 & 1.67 \\
\hline \multicolumn{9}{|l|}{ R-Square } \\
\hline Event Experience & \multicolumn{2}{|c|}{.31} & \multicolumn{2}{|c|}{.30} & \multicolumn{2}{|c|}{.41} & \multicolumn{2}{|c|}{.18} \\
\hline Fun and Entertainment & \multicolumn{2}{|c|}{.44} & \multicolumn{2}{|c|}{.52} & \multicolumn{2}{|c|}{.58} & \multicolumn{2}{|c|}{.42} \\
\hline Atmosphere & \multicolumn{2}{|c|}{.25} & \multicolumn{2}{|c|}{.28} & \multicolumn{2}{|c|}{.44} & \multicolumn{2}{|c|}{.32} \\
\hline Physical Attractiveness and Aesthetics & \multicolumn{2}{|c|}{.10} & \multicolumn{2}{|c|}{.27} & \multicolumn{2}{|c|}{.38} & \multicolumn{2}{|c|}{.25} \\
\hline Eustress and Tension & \multicolumn{2}{|c|}{.11} & \multicolumn{2}{|c|}{.05} & \multicolumn{2}{|c|}{.16} & \multicolumn{2}{|c|}{.01} \\
\hline Freedom to Move Around & \multicolumn{2}{|c|}{.00} & \multicolumn{2}{|c|}{.02} & \multicolumn{2}{|c|}{.00} & \multicolumn{2}{|c|}{.00} \\
\hline Social Contacts and Interaction & \multicolumn{2}{|c|}{.18} & & 18 & & 06 & & $\mathrm{n} / \mathrm{a}$ \\
\hline Intercultural Contact & & 01 & & 02 & & 01 & & $\mathrm{n} / \mathrm{a}$ \\
\hline
\end{tabular}

The results further reveal that event experience determines the dimensions of 
perceived value measured as the fulfilment of spectators' motivations. For all contexts, significant effects were found for all motivation dimensions except for the 'intercultural contact' and 'freedom to move around' items.

The R-square values ranging from .18 to .41 for the latent variable 'event experience' and up to .58 for the constructs measuring 'perceived value' indicate a good predictive capacity of the models. Notably, explained variance of the constructs differs between the contexts. A detailed overview of the structural model estimates is provided in Table 3.

\section{Multi-group analysis}

In order to check whether there are differences between the path coefficients for each context, an additional PLS multi-group analysis was undertaken (Sarstedt et al., 2011). A comparison of the models for the contexts 'public screening' and 'bar/pub/restaurant' reveals significant differences for the effects of 'team performance' on 'event experience' ( $\mathrm{t}$-value $=1.98, \mathrm{P}<0.05$ ). Moreover, with regard to the perceived value dimensions, the relationship between 'event experience' and 'physical attractiveness and aesthetics' significantly differs between both contexts (t-value $=1.77$, $\mathrm{p}<0.10)$. This clearly demonstrates that the context influences the overall results on key dependent constructs. The implications for this will now be discussed and avenues for future research will be outlined.

\section{Discussion and Conclusion}

This study undertakes an empirical analysis of value co-creation at the mesolevel to improve our understanding of value determination from the consumer perspective. It thereby responds to recent calls to apply service-dominant logic, the service ecosystem approach and value co-creation (Woratschek et al., 2014) to sports services and also services in general. This leads to new insights as it reflects the true 
nature of value creation that essentially requires multiple actors, who integrate resources from various private, market-facing, and public actors as well as from natural sources of resources (Horbel, 2013; Lusch \& Vargo, 2014). By applying this perspective, this study also takes into consideration that 'value is a contextually contingent concept' (Vargo, 2015, p. 14). Context is determined by the specific actors and specific resources these actors, including the beneficiary (e.g., the customer), have access to (Kleinaltenkamp, 2015) as well as the institutions and institutional arrangements that are necessary to facilitate interaction between the actors (Vargo \& Lusch, 2016). While all these elements are important to understand, this study has, as a first step, focused on the contributions of context-specific actors to sport spectators' experience and the resulting context-specific perception of value.

The results of the empirical analysis clearly reveal that both the relative influence of the contributions of the main co-creating actors on spectators' experience and the importance of the dimensions of spectators' perceived value vary considerably depending on the context, in which value was co-created. Hence, we were able to empirically demonstrate, that the context of value creation influences the structure of the service ecosystem (Chandler \& Vargo, 2011). First, the set of co-creating actors themselves differs across contexts. Second, our study reveals that the relationships between these actors, both in terms of their strength and the type of resource exchange, are also significantly shaped by the context. Our results show that those different service ecosystem constellations lead to different value perception and determination by the beneficiary (the spectator).

In the public screening context, the performance of the team $\left(\mathrm{H}_{1}\right)$ only makes a minor contribution to the overall event experience of spectators. This corresponds with the finding that 'fun and entertainment' $\left(\mathrm{H}_{4}\right)$, 'atmosphere' $\left(\mathrm{H}_{5}\right)$ and 'social contacts and 
interaction' $\left(\mathrm{H}_{9}\right)$ are the three motives that are best satisfied by public screening spectators' experience and hence represent their three most important value dimensions. These findings are in contrast to research especially in sport economics, which considers 'competitive balance' and the 'uncertainty of the outcome of the game' (e.g., Schmidt \& Berri, 2001), i.e., characteristics of the game and the performances of the teams, as most important determinants of spectators' experiences. Our findings indicate that at least in a public screening context, social aspects dominate the experience and value perception of spectators whereas game-related characteristics are less important.

In the sports bar context as well as in both viewing-at-home-contexts, spectators' experience is most importantly determined by the teams and the perception of their performance. However, even in these three contexts, value dimensions that represent the fulfilment of social motives ('fun and entertainment' $\left(\mathrm{H}_{4}\right)$, 'atmosphere' $\left.\left(\mathrm{H}_{5}\right)\right)$ are the most important dimensions of spectators' perceived value of the event experience indicating that social motives are always well satisfied by sport event experiences, regardless which actors mainly contribute to the experience. 'Physical attractiveness and aesthetics' $\left(\mathrm{H}_{6}\right)$, i.e., a dimension that is closely connected to the teams and their performance, represents the third-most important value dimension in these three contexts. This indicates that, despite the dominance of the value dimensions that more broadly reflect fun and enjoyment, there is some association between the most important actor contributions and the value dimensions most highly affected by spectators' experience.

Regarding the relative importance of actor contributions for spectators' experience and the relative importance of the different dimensions of spectators' perceived value, this study was rather exploratory in nature. However, the reasons for the dissimilarities of the two public contexts (public screening \& sports 
bar/pub/restaurant) are not as obvious. Our findings indicate, that spectators might seek and prefer public screenings when they want to interact with their friends and other people during the game whereas they might choose to watch the games in a sports bar, pub or restaurant when they are more strongly interested in the game. However, based on this study we are not yet able to clarify the direction of this effect. On the one hand, spectators with different preferences might choose the context which provides the most suitable resources to satisfy the motives (value dimensions) that are most important to them. Thus, the contexts could stimulate a self-selection mechanism of spectators. On the other hand, the contextual differences regarding the involved actors and resources available might lead to different perceptions, both regarding the importance of particular actors' contributions to the experience and the level of satisfaction of particular motives as dimensions of perceived value. We believe that both mechanisms apply (Vargo \& Lusch, 2016) and suggest that future research should reveal the dominant direction of this effect by investigating the relative strength of these processes, for example through experiments.

Regardless of this, our findings are important from a practitioner's perspective as they indicate that service providers are probably confronted with different spectator types and expectations depending on the context in which they operate. We recommend that they should carefully research and identify the core value dimensions that are important for the experience of their customers in order to successfully contribute to value co-creation and achieve strategic benefit (Lusch \& Vargo, 2014). For example, we recommend that service providers involved in staging public screening events are aware that social interactions are important for their visitors and focus on providing them a platform, which enables viewers to connect and co-create the event experience.

Our results have demonstrated that spectators at public screening events 
essentially derive value from social interaction $\left(\mathrm{H}_{9}\right)$ as well as hedonic components such as atmosphere $\left(\mathrm{H}_{5}\right)$ and fun and entertainment $\left(\mathrm{H}_{4}\right)$. Hence, public screenings seem to offer a surrogate format to experience the event within the broader collective to try and best recreate actually being within or at the venue. This virtual transformation is very important for modern societies (especially for mega events where country teams or national athletes feature) as it builds community and nationalistic identity and attachment. It assists to support people's friendly exchanges and enhances city or place building. The audience can become attached to these viewing monuments. It is further valuable as it links the people in a real time context with the event. There is a collective 'we are in it together feeling'. It should be stressed that these events are not always friendly viewing forums as many cities have culturally diverse communities that may not always be agreeable with the underlying sporting result or the event itself. Hence, there is also a potential risk for conflict and social disharmony.

Our findings are further in line with media research which emphasizes that the presence of co-viewers increases the user's overall level of enjoyment and enhances the endurability of the experience (Zhu, Heynderickx, \& Redi, 2015). This is a notable finding, but it must be recognized that this study could be improved by consecutively garnering information from individuals and also other important viewing dyads (e.g., close friends, a family group or even a group of supporters that converge to watch games together consistently).

Across contexts, 'intercultural contact' $\left(\mathrm{H}_{10}\right)$ is shown to be of limited influence, which is surprising given the tournament's international status. However, it could be due to the fact, that the participants in our study watched the games at a long distance from the actual event and therefore had only limited opportunity to interact with people from other cultures. 
In this study, the flexibility of the data analysis technique PLS has demonstrated some clear results by highlighting that context really does change the overall predictive utility of the model and that the drivers are respectively different. Our findings therefore support the notion of value as 'value-in-context' and advise researchers in sport management pick up this perspective in future studies.

\section{Limitations and further research}

We currently consider this an exploratory investigation. Future research should use larger sample sizes to be able to report effect size differences between contexts more comprehensively. This should also include the consideration of other contextspecific characteristics. For example, in this research, sample size allowed us to test for differences regarding the stage of competition (group stage vs. knockout stage) for the context of 'watching on TV with friends'. The PLS multi-group analysis (Ringle, Wende, \& Becker, 2015) did not reveal any significant differences of the path coefficients within the structural model. Further research using larger sample sizes might have a closer look at more nuanced differences between different games including additional context-specific aspects (e.g., result of the game, rivalry among teams).

While this study has taken a meso-perspective of analysis of value co-creation, we have only taken the customer's (spectator's) perspective as a beneficiary from this process and focused on resource integration and value perception from this point of view. This perspective should be broadened in future studies and include similar investigations for other participating actors as in service ecosystems all actors are connected through mutual service exchange and resource integration.

Considering the context of consumption is a meaningful direction for further research in order to gain new insights into sport-specific phenomena. Further studies 
should compare value co-creation at live sport events with the broadcasting contexts that have been included in this study. Another avenue for future research would be to look at co-creation of value-in-context at different levels, the intra-level, micro-level and macro-level in particular, and to combine and discuss insights from these different levels of analysis (Lusch \& Vargo, 2014; Woratschek et al., 2014). This would allow for a more holistic understanding of event experience and value creation from a service ecosystems perspective.

We would suggest that further context-within-context research be undertaken. Some stadiums and telecommunications service providers not allow real-time viewing of sport on screens or smartphones whilst you are actually at the game itself.

While this study has been focused on an analysis of the contributions and influence of the actors in different value creation contexts, further research should expand this perspective by studying the structural dimension of social context, i.e. the influence of societal norms, values and habits in order to better understand various actors' value perceptions (Edvardsson et al., 2011).

Finally, as value creation and perception cannot be understood without an understanding of context (Vargo et al., 2008), this research should be replicated in other service contexts.

\section{References}

Achrol, R. S., \& Kotler, P. (1999). Marketing in the network economy. Journal of Marketing, 63(Special Issue 1999), 146-163.

Akaka, M. A., Vargo, S. L., \& Schau, H. J. (2015). The context of experience. Journal of Service Management, 26(2), 206-223.

Arnould, E. J. (2007). Service-dominant logic and consumer culture theory: Natural allies in an emerging paradigm. Research in Consumer Behavior, 11, 57-76. 
Arnould, E. J., \& Thompson, C. J. (2005). Consumer Culture Theory (CCT): Twenty Years of Research. Journal of Consumer Research, 31(4), 868-882.

Beccarini, C., \& Ferrand, A. (2006). Factors Affecting Soccer Club Season Ticket Holders' Satisfaction: The Influence of Club Image and Fans' Motives. European Sport Management Quarterly, 6(1), 1-22.

Becker, K., Kautsky, R., \& Widholm, A. (2014). Watching football in the fan park: mediatization, spectatorship and fan identity. In L. Duits, K. Zwaan \& S. Reijnders (Eds.), The Ashgate research companion to fan cultures (pp. 275288). Farnham: Ashgate.

Bouchet, P., Bodet, G., Bernache-Assollant, I., \& Kada, F. (2011). Segmenting sport spectators: Construction and preliminary validation of the Sporting Event Experience Search (SEES) scale. Sport Management Review, 14(1), 42-53.

Brady, M. K., \& Cronin, J. J. (2001). Some New Thoughts on Conceptualizing Perceived Service Quality: A Hierarchical Approach. Journal of Marketing, 65(3), 34-49.

Chandler, J. D., \& Vargo, S. L. (2011). Contextualization and value-in-context: How context frames exchange. Marketing Theory, 11(1), 35-49.

Chang, T.-Y., \& Horng, S.-C. (2010). Conceptualizing and measuring experience quality: the customer's perspective. The Service Industries Journal, 30(14), 2401-2419.

Chin, W. W. (1998). The partial least squares approach for structural equation modeling. In G. A. Marcoulides (Ed.), Modern methods for business research (pp. 295-336). Mahwah: Lawrence Erlbaum.

Chin, W. W. (2010). How to Write Up and Report PLS Analyses. In V. Esposito Vinzi, W. W. Chin, J. Henseler \& H. Wang (Eds.), Handbook of Partial Least Squares: 
Concepts, Methods and Applications in Marketing and Related Fields (pp. 655690). Berlin: Springer.

Donavan, D. T., Carlson, B. D., \& Zimmermann, M. (2005). The Influence of Personality Traits on Sports Fan Identification. Sport Marketing Quarterly, 14(1), 31-42.

Durchholz, C. (2012). Ko-Kreation von Werten im Dienstleistungsmanagement: Eine empirische Analyse des Einflusses anderer Personen bei Sportevents. Berlin: Springer.

Edvardsson, B., Enquist, B., \& Johnston, R. (2005). Cocreating Customer Value Through Hyperreality in the Prepurchase Service Experience. Journal of Service Research, 8(2), 149-161.

Edvardsson, B., Tronvoll, B., \& Gruber, T. (2011). Expanding understanding of service exchange and value co-creation: a social construction approach. Journal of the Academy of Marketing Science, 39(2), 327-339.

Fernandes, T., \& Neves, S. (2014). The role of servicescape as a driver of customer value in experience-centric service organizations: the Dragon Football Stadium case. Journal of Strategic Marketing, 22(6), 548-560.

Fornell, C., \& Larcker, D. F. (1981). Evaluating structural equation models with unobservable variables and measurement error. Journal of Marketing Research, 18(1), 39-50.

Fournier, S. (1998). Consumers and their brands: Developing relationship theory in consumer research. Journal of Consumer Research, 24(4), 343-373.

Funk, D. C., Mahony, D. F., \& Ridinger, L. L. (2002). Characterizing consumer motivation as individual difference factors: augmenting the Sport Interest Inventory (SII) to explain level of spectator support. Sport Marketing Quarterly, 
11(1), 33-43.

Funk, D. C., Ridinger, L. L., \& Moorman, A. M. (2004). Exploring Origins of Involvement: Understanding the Relationship Between Consumer Motives and Involvement with Professional Sport Teams. Leisure Sciences, 26(1), 35-62.

Gerhard, H., \& Zubayr, C. (2014). Die Fußball-Weltmeisterschaft 2014 im Fernsehen Daten zur Rezeption und Bewertung. Media Perspektiven(9), 447-455.

Gladden, J. M., \& Funk, D. C. (2001). Understanding Brand Loyalty in Professional Sport: Examining the Link between Brand Associations and Brand Loyalty. International Journal of Sports Marketing and Sponsorship, 3(1), 67-94.

Grönroos, C., \& Voima, P. (2013). Critical service logic: making sense of value creation and co-creation. Journal of the Academy of Marketing Science, 41(2), 133-150.

Hair, J. F., Sarstedt, M., Ringle, C. M., \& Mena, J. A. (2012). An assessment of the use of partial least squares structural equation modeling in marketing research. Journal of the Academy of Marketing Science, 40(3), 414-433.

Harman, H. H. (1976). Modern factor analysis (3 ed.). Chicago: University of Chicago Press.

Helkkula, A., Kelleher, C., \& Pihlström, M. (2012). Characterizing Value as an Experience: Implications for Service Researchers and Managers. Journal of Service Research, 15(1), 59-75.

Henseler, J., Ringle, C. M., \& Sinkovics, R. R. (2009). The use of partial least squares path modeling in international marketing. In R. R. Sinkovics \& P. N. Ghauri (Eds.), New Challenges to International Marketing (pp. 277-319). Bingley: Emerald.

Horbel, C. (2013). Service-dominant logic and tourism management. Enriching each other. Business Administration Review, 73(2), 131-142. 
James, J. D., \& Ross, S. D. (2004). Comparing sport consumer motivations across multiple sports. Sport Marketing Quarterly, 13(1), 17-25.

Kleinaltenkamp, M. (2015). Value Creation and Customer Effort - The Impact of Customer Value Concepts. In J. Gummerus \& C. von Koskull (Eds.), The Nordic School. Service Marketing and Management for the Future (pp. 283292). Helsinki: Hanken Schools of Economics.

Lam, S. K., Ahearne, M., Mullins, R., Hayati, B., \& Schillewaert, N. (2013). Exploring the dynamics of antecedents to consumer-brand identification with a new brand. Journal of the Academy of Marketing Science, 41(2), 234-252.

Li, M., Hofacre, S., \& Mahony, D. (2001). Economics of Sport. Morgantown, WV: Fitness Information Technology.

Lull, J. (1980). The Social Uses of Television. Human Communication Research, 6(3), 197-209.

Lusch, R. F., \& Vargo, S. L. (2014). Service-Dominant Logic: Premises, Perspectives, Possibilities. Camebrige: Camebridge University Press.

Macdonald, E. K., Wilson, H., Martinez, V., \& Toossi, A. (2011). Assessing value-inuse: A conceptual framework and exploratory study. Industrial Marketing Management, 40(5), 671-682.

Madrigal, R. (1995). Cognitive and affective determinants of fan satisfaction with sporting event attendence. Journal of Leisure Research, 27(3), 205-227.

Mael, F. A., \& Ashforth, B. E. (1992). Alumni and their Alma Mater: A Partial Test of the Reformulated Model of Organizational Identification. Journal of Organizational Behavior, 13(2), 103-123.

Maglio, P. P., Vargo, S. L., Caswell, N., \& Spohrer, J. (2009). The service system is the basic abstraction of service science. Information Systems and e-business 
Management, 7(4), 395-406.

Payne, A. F., Storbacka, K., \& Frow, P. (2008). Managing the co-creation of value. Journal of the Academy of Marketing Science, 36(1), 83-96.

Pfisterer, L., \& Roth, S. (2015). Customer usage processes: A conceptualization and differentiation. Marketing Theory, 15(3), 401-422.

Podsakoff, P. M., MacKenzie, S. B., \& Podsakoff, N. P. (2012). Sources of method bias in social science research and recommendations on how to control it. Annual review of psychology, 63, 539-569.

Prahalad, C. K., \& Ramaswamy, V. (2004). Co-creating unique value with customers. Strategy \& Leadership, 32(3), 4-9.

Reinartz, W., Haenlein, M., \& Henseler, J. (2009). An empirical comparison of the efficacy of covariance-based and variance-based SEM. International Journal of Research in Marketing, 26(4), 332-344.

Ringle, C. M., Wende, S., \& Becker, J.-M. (2015). SmartPLS 3. Hamburg: SmartPLS. Retrieved from http://www.smartpls.com

Sarstedt, M., Henseler, J., \& Ringle, C. M. (2011). Multigroup Analysis in Partial Least Squares (PLS) Path Modeling: Alternative Methods and Empirical Results. In M. Sarstedt, M. Schwaiger \& C. R. Taylor (Eds.), Measurement and Research Methods in International Marketing (pp. 195-218): Emerald Group Publishing Limited.

Schafmeister, G. (2007). Sport im Fernsehen - Eine Analyse der Kundenpräferenzen für mediale Dienstleistungen. Wiesbaden: Gabler.

Schmidt, M. B., \& Berri, D. J. (2001). Competitive Balance and Attendance - The Case of Major League Baseball. Journal of Sports Economics, 2(2), 145-167.

Schouten, J. W., \& McAlexander, J. H. (1995). Subcultures of Consumption: An 
Ethnography of the New Bikers. Journal of Consumer Research, 22(6), 43-61.

Stokburger-Sauer, N., Bauer, H. H., \& Mäder, R. (2008). Kundenidentifikation als Basis von Kundenloyalität - Theoretische und empirische Grundlagen für eine Umsetzung in der Unternehmenspraxis. Zeitschrift für Betriebswirtschaft, 78(9), 923-950.

Tajfel, H. (1978). Social categorization, social identity and social comparison. In H. Tajfel (Ed.), Differentiation Between Social Groups: Studies in the Social Psychology of Intergroup Relations (pp. 61-76). London: Academic Press.

Tomorrow Focus Media. (2014). Social Trends WM 2014. München, Germany.

Trail, G. T., Anderson, D. F., \& Fink, J. S. (2003). Sport spectator consumption behavior. Sport Marketing Quarterly, 12(1), 8-17.

Trail, G. T., \& James, J. D. (2001). The Motivation Scale for Sport Consumption: Assessment of the Scale's Psychometric Properties. Journal of Sport Behavior, 24(1), 108-127.

Tsiotsou, R. H. (2016). The social aspects of consumption as predictors of consumer loyalty: Online vs offline services. Journal of Service Management, 27(2), 91116.

Tsiotsou, R. H., \& Vargo, S. L. (2015). The Application of Service-Dominant Logic in Sport Services. Paper presented at the Naples Forum on Services, Naples, Italy.

Uhrich, S., \& Benkenstein, M. (2010). Sport Stadium Atmosphere: Formative and Reflective Indicators for Operationalizing the Construct. Journal of Sport Management, 24(2), 211-237.

Uhrich, S., \& Benkenstein, M. (2012). Physical and social atmospheric effects in hedonic service consumption: customers' roles at sporting events. The Service Industries Journal, 32(11), 1741-1757. 
Vargo, S. L. (2009). Toward a transcending conceptualization of relationship: a servicedominant logic perspective. Journal of Business \& Industrial Marketing, 24(5/6), 373-379.

Vargo, S. L., \& Akaka, M. A. (2012). Value cocreation and service systems (re) formation: A service ecosystems view. Service Science, 4(3), 207-217.

Vargo, S. L., \& Lusch, R. F. (2004). Evolving to a New Dominant Logic for Marketing. Journal of Marketing, 68(1), 1-17.

Vargo, S. L., \& Lusch, R. F. (2008). Service-Dominant Logic: Continuing the Evolution. Journal of the Academy of Marketing Science, 36(1), 1-10.

Vargo, S. L., \& Lusch, R. F. (2011). It's all B2B... and beyond: Toward a systems perspective of the market. Industrial Marketing Management, 40(2), 181-187.

Vargo, S. L., \& Lusch, R. F. (2016). Institutions and axioms: an extension and update of service-dominant logic. Journal of the Academy of Marketing Science, 44(1), 523.

Wakefield, K. L., \& Blodgett, J. G. (1994). The Importance of Servicescapes in Leisure Service Settings. Journal of Services Marketing, 8(3), 66-76.

Wakefield, K. L., Blodgett, J. G., \& Sloan, H. J. (1996). Measurement and Management of the Sportscape. Journal of Sport Management, 10(1), 15-31.

Wang, T. R., Min, S. D., \& Kim, S. K. (2013). Fulfillment of sport spectator motives: The mediation effect of well-being. Social Behavior \& Personality: an international journal, 41(9), 1421-1434.

Wann, D. L. (1995). Preliminary Validation of the Sport Fan Motivation Scale. Journal of Sport and Social Issues, 19(1), 377-397.

Weed, M. (2007). The pub as a virtual football fandom venue: an alternative to 'being there'? Soccer \& Society, 8(2-3), 399-414. 
White, K., Argo, J. J., \& Sengupta, J. (2012). Dissociative versus Associative Responses to Social Identity Threat: The Role of Consumer Self-Construal. Journal of Consumer Research, 39(4), 704-719.

Wilson, B. (2010). Using PLS to Investigate Interaction Effects Between Higher Order Branding Constructs. In V. Esposito Vinzi, W. W. Chin, J. Henseler \& H. Wang (Eds.), Handbook of Partial Least Squares: Concepts, Methods and Applications in Marketing and Related Fields (pp. 621-652). Berlin/Heidelberg: Springer.

Won, J.-u., \& Kitamura, K. (2007). Comparative analysis of sport consumer motivations between South Korea and Japan. Sport Marketing Quarterly, 16(2), 93-105.

Woratschek, H., Horbel, C., \& Popp, B. (2014). The sport value framework - a new fundamental logic for analyses in sport management. European Sport Management Quarterly, 14(1), 6-24.

Wu, C. H.-J. (2008). The influence of customer-to-customer interactions and role typology on customer reaction. The Service Industries Journal, 28(10), 15011513.

Zhu, Y., Heynderickx, I., \& Redi, J. A. (2015). Understanding the role of social context and user factors in video Quality of Experience. Computers in Human Behavior, $49,412-426$. 


\title{
Appendix.
}

\author{
Team Performance (Beccarini \& Ferrand, 2006; Madrigal, 1995) \\ The national team of $\mathrm{X}$ performed very well. \\ The national team of $X$ showed great devotion to the game. \\ The game was extremely thrilling. \\ Spectator-Induced Atmosphere (adapted from Uhrich \& Benkenstein, 2010, 2012) \\ The fans were producing a sweeping atmosphere and there was gigantic enthusiasm. \\ I liked the football chants and actions of the fans. \\ The fans were backing the team during the game. \\ Service Quality Consumption Context ${ }^{\mathrm{a}, \mathrm{b}}$ (self-developed)
}

Venue, infrastructure, gastronomy and organization at stadium/at the Public Viewing/at the bar/pub/restaurant were outstanding. ${ }^{\text {a,b }}$

The services at the game/at the Public Viewing/at the bar/pub/restaurant were of high quality. ${ }^{\mathrm{a}, \mathrm{b}}$

The offerings in the stadium/at the Public Viewing/at the bar/pub/restaurant were excellent. ${ }^{\mathrm{a}, \mathrm{b}}$

The organizers took care for offering a great football experience at the stadium/at the Public Viewing/at the

bar/pub/restaurant., ${ }^{\text {ab }}$

Event Experience

To what degree did the game $\mathrm{X}$ vs. Y match your expectation of a perfect football experience?

Fun and Entertainment (adapted from James \& Ross, 2004; Won \& Kitamura, 2007)

I had a lot of fun watching the game.

The game was a positive experience.

Atmosphere (adapted from Uhrich \& Benkenstein, 2010, 2012)

There was tremendous enthusiasm.

There was a great atmosphere.

There was a thrilling euphoria.

Physical Attractiveness and Aesthetics (adapted from Trail et al., 2003)

I enjoyed the skillful performance of the teams.

I enjoyed watching a well-executed athletic performance.

The athletic skills of the players were something I appreciated.

Eustress and Tension (adapted from Funk, Ridinger, \& Moorman, 2004; Wann, 1995)

I enjoyed the excitement of the game.

I was thrilled by the game.

I enjoyed the drama of the game.

Freedom to Move Around (self-developed)

I watched the game at the Public Viewing/at a bar/pub/restaurant/together with friends at home/at home because, in contrast to the stadium, you can freely move around.

I watched the game at the Public Viewing/at a bar/pub/restaurant because the fans of both teams are not separated from each other. ${ }^{\mathrm{a}, \mathrm{b}}$

Social Contacts and Interaction ${ }^{\mathrm{b}}$ (Trail et al., 2003)

I enjoyed interacting with other people. , $^{\mathrm{a} b}$

I enjoyed socializing with other people. , $^{\mathrm{a}, \mathrm{b}}$

Intercultural Contact ${ }^{\mathrm{b}}$ (self-developed)

I watched the game at the stadium/at a bar/pub/restaurant/together with friends at home because I like to interact with people from other cultures. ${ }^{\mathrm{b}}$

I watched the game at the stadium/at a bar/pub/restaurant/together with friends at home because you can peacefully celebrate with the fans of the opposing team. ${ }^{\mathrm{b}}$

\section{Identification National Team}

(adapted from Donavan et al., 2005; Mael \& Ashforth, 1992; Trail et al., 2003)

I consider myself to be a 'real' fan of the national team of X.

Being a fan of the national team of $\mathrm{X}$ is very important to me.

I identify with the national team of X.

I have the feeling to be part of the fans of the national team of X.

I am happy to be a part of the fans of the national team of X.

I feel very committed to the national team of $X$.

\section{Identification FIFA World Cup}

(adapted from Donavan et al., 2005; Mael \& Ashforth, 1992; Trail et al., 2003)

I consider myself to be a 'real' fan of the FIFA World Cup.

Being a fan of the FIFA World Cup is very important to me.

I identify with the FIFA World Cup.

I have the feeling to be part of the fans of the FIFA World Cup.

I am happy to be a part of the fans of the FIFA World Cup.

I feel very committed to the FIFA World Cup.

Notes: a = not applicable for context 'together with friends at home'; b =not applicable for the context 'alone at home'. 